\title{
PERBAIKAN TEKNOLOGI PENGOLAHAN, MODIFIKASI BENTUK DAN UKURAN, SERTA PENGEMBANGAN PRODUK ALTERNATIF GULA AREN
}

\section{TECHNOLOGY IMPROVEMENT ON PROCESSING, FORM AND SIZE MODIFICATION, AND PALM SUGAR ALTERNATIVE PRODUCT DEVELOPMENT}

\author{
Oleh: \\ Wuri Marsigit \\ Jurusan Teknologi Pertanian, Fakultas Pertanian, Universitas Bengkulu
}

\begin{abstract}
This project aims to provide knowledge, skills and facilitate the producers in improving the product quality and marketing through the improvement of product. This project was conducted by establishing demo plots to selected palm sugar producers. The activities include providing extension, workshops on processing, packaging technologies for palm sugar, entrepreneurship vision, business management, and strategic for marketing. This project successfully introduced the suitable technologies to produce more hygienic palm sugar with more interesting shape, more uniform in size, more long-lasting shelf-life compared to previous technologies applied by the producers. In addition, the introduction of plastic pipe made the palm sugar sap is much more sterilized and cleaner than the bamboo-based technology and furnace modification can improve processing 48 minutes faster than before and save energy up to $23 \%$. Although the introduced technology to process the palm sugar did not change the nutrients content, the product quality met the SNI standards. The introduced techniques also prolong the shelf life from 24 days to 126 days. There was not any difference in terms of selling prices to both products. However, the price of alternative product (powdery brown sugar) was almost 4 times higher than the traditional products (block palm sugar).
\end{abstract}

Keywords: Processing, size, shape, packaging, quality, and marketing

\section{PENDAHULUAN}

Aren merupakan salah satu komoditas andalan spesifik lokasi Kaupaten Rejang Lebong, Propinsi Bengkulu. Meskipun masih diusahakan secara alami, namun areal tanaman aren di Kabupaten Rejang Lebong cukup luas.

Gula aren merupakan komoditas yang potensial untuk dikembangkan sebagai andalan ekspor nonmigas di Propinsi Bengkulu, terutama dimasa-masa krisis belakangan ini (Dinas Perindustrian dan Perdagangan Provinsi Bengkulu, 2007). Negara-negara yang membutuhkan gula aren antara lain: Saudi Arabia, Amerika Serikat, Australia, Selandia Baru, Jepang, Kanada, Singaoura, Malaysia, dan Brunei Darussalam namun permintaan tersebut tidak pernah terpenuhi karena terkendala pada kualitas, kuantitas dan kontinuitas produk (Lay dan Bambang, 2011). 
Gula aren merupakan gula alternatif yang perlu dikembangkan sebagai gula lain selain gula tebu yang produksinya akhir-akhir ini mengalami penurunan yang sangat drastis, sehingga Indonesia cenderung mengimpor gula dari luar. Ditinjau dari aspek kesehatan, gula aren mempunyai beberapa kelebihan dibandingkan gula pasir atau gula tebu (Sapari, 1995). Gula aren diproses secara alami (tradisional) dan tidak menggunakan bahan-bahan kimia. Kalaupun ada hanya sebagai pengawet. Gula aren juga mengandung glukosa lebih banyak dibandingkan gula tebu.

Desa Air Meles, Kecamatan Selupu Rejang, merupakan salah satu sentra produksi aren di Kabupaten Rejang Lebong. Teknologi pengolahan gula aren di desa ini masih belum begitu baik sehingga kualitas dan produktivitasnya sangat rendah. Secara umum petani aren di desa ini melakukan kegiatan pasca panen nira, setelah disadap langsung dibawa pulang ke tempat pengolahan. Air nira langsung dituang ke dalam kuali (wajan) dan tidak dilakukan penyaringan untuk menghindari terbawanya kotoran, serangga, tanah dan sebagainya, selanjutnya langsung dimasak. Beberapa petani menumpuk dulu air nira selama sehari, kemudian baru dimasak; namun hasil gula niranya kurang baik. Pengolahan gula aren di desa ini pada umumnya masih dilakukan dengan cara sangat sederhana dengan menggunakan peralatan tradisional seperti kuali, tungku kayu bakar, sendok kayu, peniup api dari bambu, pencetak gula dari tempurung. Seluruh pengrajin menggunakan bahan bakar dari kayu untuk memasak gula aren.

Dari hasil penelitian sebelumnya diperoleh gambaran bahwa proses pengolahan masih sangat sederhana sehingga kualitas dan nilai tambah gula aren yang dihasilkan kurang bagus, warna kelam, gampang meleleh, kurang bersih dan penampilan kurang menarik. Penyebab kualitas kurang baik antara lain:

1. Sebagian besar Pengrajin menggunakan deterjen untuk mencegah keasaman nira. Bentuk dan ukuran tidak seragam, sehingga ketika dibeli dalam bentuk kiloan harus di potongpotong sebagian agar timbangan pas.

2. Penggunaan tabung bambu sebagai penampung dapat mengakibatkan nira mudah asam. Nira yang asam tidak dapat diolah menjadi gula aren.

3. Nira yang diperoleh tidak dilakukan penyaringan, sehingga pada saat diolah, bendabenda asing.

4. Bentuk cetakan hanya terbuat dari batok kelapa, sehingga kurang menarik.

5. Pengunaan tungku dengan sistem terbuka, sehingga pembakaran sangat cepat dan menyebabkan boros bahan bakar kayu.

6. Gula aren hanya satu-satunya produk tanaman aren di Propinsi Bengkulu, belum ada produk alternatif lainnya.

Tujuan kegiatan ini adalah:

1. Memberikan pengetahuan, keterampilan dan mengaplikasikan teknologi pengolahan gula aren yang standar dengan penerapan IPTEK yang sederhana kepada mitra binaan agar nantinya dapat ditularkan kepada pengrajin lainnya.

2. Melakukan pembinaan dan pendampingan untuk meningkatkan kualitas dan nilai tambah produk agar dapat menjangkau jalur pemasaran yang lebih luas, dengan menyeragamkan 
bentuk, ukuran dan timbangan; serta membuat produk alternatif.

3. Membuat kemasan yang semenarik mungkin agar dapat dijual sebagai oleh-oleh wisatawan yang berkunjung ke Bengkulu;

4. Memperkenal model tungku yang lebih hemat bahan bakar agar pengeluaran untuk pembelian bahan bakar menurun.

5. Miningkatkan nilai tambah produk agar penerimaan pengrajin meningkat dan sekaligus memutus siklus ketergantungan terhadap tengkulak (ulo).

Dengan kegiatan ini diharapkan:

1. Dengan efisiensi penggunaan bahan bakar dapat menurunkan pengeluaran bahan bakar, sehingga penerimaan pengrajin meningkat.

2. Dengan mengganti deterjen sebagai pencegah keasaman dengan produk lain yang lebih aman, akan menjamin keamanan produk di pasaran.

3. Dengan pengolahan yang standar, efisien dan sederhana dapat meningkatkan kualitas

4. Dengan pembuatan produk alternatif akan dapat meningkatkan nilai tambah.

5. Peningkatan nilai tambah dan kualitas akan dapat pendapatan pengrajin binaan pada khususnya, pengrajin Desa Air Meles dan Rejang Lebong pada umumnya.

Dari hasil pendataan Perindag Propinsi Bengkulu, Pengrajin Gula aren di Kabupaten Rejang mencapai 9.873 pengrajin, sementara di Propinsi Bengkulu terdapat 11.349 pengrajin yang tersebar di Kabupaten Rejang Lebong, Bengkulu Utara dan Bengkulu Selatan. Jika teknologi ini dapat ditularkan maka diharapkan dapat meningkatkan pendapatan seluruh pengrajin di Rejang Lebong pada khususnya dan Kabupaten lain pada umumnya. Secara regional dapat meningkatkan PDRB, sedangkan secara nasional dapat meningkatkan ekspor non migas Indonesia, apabila produk tersebut dapat diekspor. Dengan kualitas yang baik dan produk alternatif dengan nilai tambah tinggi, angkat meningkatkan harga harga gula aren. Harga gula aren yang tinggi diharapkan dapat mendorong petani atau investor untuk memperluas luas areal tanaman aren di Provinsi Bengkulu yang selama ini masih belum dibudidyakan, masih tumbuh dan menyebar secara alami (Marsigit, 2010). Kawasan tanaman tanaman dapat berfungsi ganda yaitu sebagai kawasan konservasi dan sumber pendapatan masyarakat. Apalagi tanaman aren dapat dimanfaatkan secara optimal tanpa merusak lingkungan seperti ijuknya, akarnya, batang yang sudah mati, lidi, buah (kolang-kaling).

\section{METODE PENGABDIAN}

Kegiatan ini dimaksudkan untuk memberikan pengetahuan, keterampilan dan mengaplikasikan teknologi pengolahan gula aren yang standar kepada mitra binaan (Bapak Sumarno) agar nantinya dapat ditularkan kepada pengrajin lainnya; melakukan pembinaan dan pendampingan untuk meningkatkan kualitas produk agar dapat menjangkau jalur pemasaran yang lebih luas, dengan menyeragamkan bentuk, ukuran dan timbangan; membuat kemasan yang semenarik mungkin; mensosialisasikan teknologi yang diperkenalkan dan diapalikasikan kepada pengrajin gula yang lain; meningkatkan nilai 
tambah produk agar penerimaan pengrajin meningkat dan sekaligus memutus siklus ketergantungan terhadap tengkulak $(u l o)$.

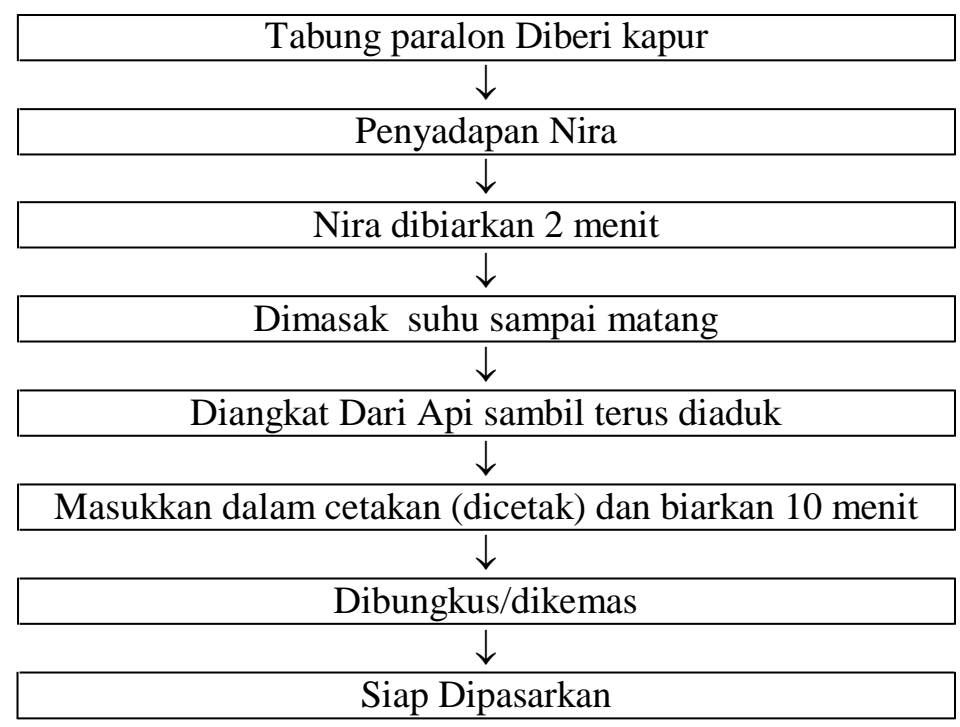

Gambar 1. Diagram Alir Pembuatan Gula Aren yang Baik

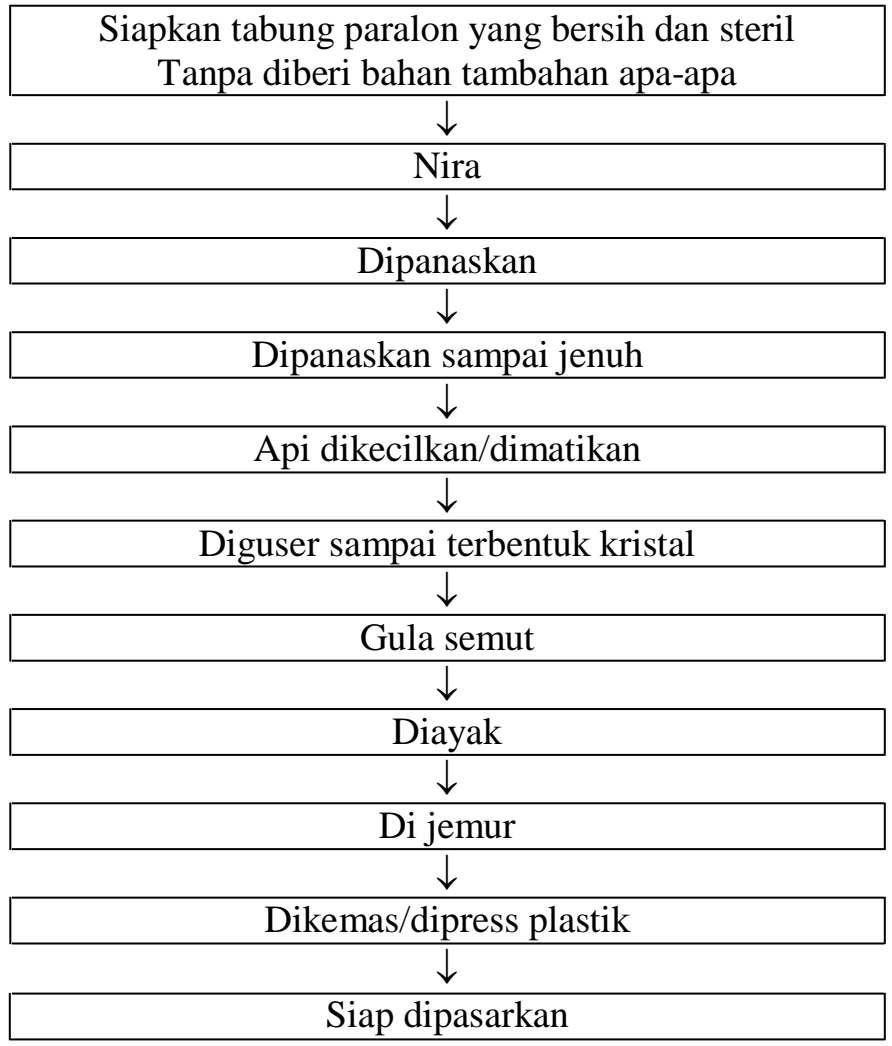

Gambar 2. Diagram Alir Pembuatan Gula Semut

Bahan dan alat yang dipakai antara lain kapur sirih, nira aren, plastik kemasan, tabung paralon yang dimodifikasi jadi alat penampung, saringan nira, palstik sealer, model 
pengembangan tungku, cetakan gula, kuali, penggerus (pembuat gula semut).

Metode yang digunakan pada kegiatan ini mengadakan plot demonstrasi pada pengrajin gula raen terpilih di Kegiatan dalam di dalam plot demomtrasi meliputi :

1. Penyuluhan dan diskusi tentang wawasan kewirausahaan, manajemen usaha, teknologi pengolahan dan pengawetan, teknologi pengemasan, dinamika kelompok dalam pengembangan usaha dan pemasaran.

2. Pembinaan dan pendampingan (termasuk demonstrasi/praktek pengolahan) tentang, model tungku yang hemat energi, standardisasi proses pengolahan, bentuk, ukuran dan timbangan untuk meingkatkan kualitas produk, pembuatan gula semut sebagai produk alternatif.

3. Membuat desain cetakan yang seragam dengan membuat kemasan yang menarik agar dapat dipasarkan dengan harga tinggi dan jaringan pasar yang lebih pasar.

\section{HASIL DAN PEMBAHASAN}

Dari hasil kegiatan yang telah dilakukan dapat diaplikasikan teknologi tepat guna untuk menghasilkan produk gula aren dan gula semut yang bersih, tahan lama, higienis dan bentuk menarik dan ukuran yang relatif seragam dibandingkan dengan teknologi sebelumnya. Dengan perbaikan teknologi yang diaplikasikan dapat menghemat penggunaan bahan bakar hingga 23\%. Dengan cara yang lama model tungku di atas tanah mengakibatkan pembakaran yang terbuka yang boros bahan bakar kayu, dimana panasnya menyebar ke segala arah, sehingga panas yang dihasilkan tidak terkonsentrasi wajan pemasak nira. Pada kegiatan ini tungku dibuat masuk ke dalam tanah dengan diberikan lubang masuk udara berupa corong di permukaan tanah. Dengan cara ini pembakaran menjadi lebih efisien bahan bakar, karena pembakaran tidak terbuka, tetapi semi tertutup. Api yang dihasilkan lebih terkonsentrasi pada wajan pemasak nira. Dengan cara ini pemasakan bisa lebih cepat 48 menit dibandingkan cara sebelumnya.

Disamping itu cara pembersihan dan sterilisasi yang lebih mudah karena alat penampung yang terbuat dari paralon bersifat lebih kedap dibandingkan bambu. Seperti diketahu bahwa bambu mempunyai sifat porositas yang tinggi, sehingga proses pembersihan dan sterilisasi kurang sempurna. Porositas tersebut menyebabkan sebagian nira yang masuk ke dalam bambu sebagian masih mengalami proses fermentasi. Keadaan ini dapat mengakibatkan nira yang ditampung berikutnya akan mudah asam, sehingga ketika dimasak tidak jadi, meskipun jadi kualitasn gulanya tidak baik (mudah lembek). Dari hasil pengamatan di lapangan nira dengan $\mathrm{pH}$ rendah (bersifat asam) mempunyai korelasi dengan penurunan kadar brix nira, kadar brix nira yang rendah ini menyebabkan kadar gulanya rendah, sehingga ketika dimasak agak kurang baik hasilnya.

Nira yang terlalu lama dibiarkan tidak diolah cenderung terjadi penurunan $\mathrm{pH}$ (menjadi asam) dan penurunan kadar gula (brix), karena gula yang ada pada nira cenderung mengalami perubahan (fermentasi) menjadi asam. Keadaan ini yang menyebabkan nira yang diolah tidak menjadi gula (Sapari, 1995; Lay dan Bambang, 2011). 
Beragamnya kualitas nira tersebut tidak terlepas dari varietas tanaman, kondisi agroklimat, kesuburan tanah, dan perlakuan sebelum penyadapan. Perlakuan sebelum penyadapan dengan memberikan bahan tambahan pada tabung menunjukkan adanya perbedaan yang berarti (Marsigit, 2004). Penambahan bahan tambahan seperti deterjen (rinso) dapat menghasilkan nira yang lebih jernih dibandingkan yang tidak menggunakan sama sekali. Bahkan dengan penambahan deterjen dapat mempertahankan $\mathrm{pH}$ dan kadar brix layak diolah yang cukup lama dibandingkan dengan perlakuan lainnya. Namun demikian penambahan deterjen ini tidak dianjurkan dalam proses pengolahan gula aren, karena deterjen adalah tergolong sebagai bahan pembersih bukan bahan tambahan makanan (tidak termasuk bahan tambahan makanan sesuai Peraturan Menteri Kesehatan RI No. 722/Menkes/Per/IX/1988 tentang Bahan Tambahan Makanan) dan disinyalir dapat membahayakan bagi kesehatan (Marsigit, 2004). Bahan tersebut diganti dengan kapur sirih yang mempunyai fungsi yang sama yaitu untuk mencegah penurunan $\mathrm{pH}$, kadar brix dan memang diizinkan penggunaannya. Dalam prakteknya tidak semua nira yang dikumpulkan oleh para penyadap tergolong dalam kriteria nira yang baik. Beragamnya nira ini juga akan menghasilkan jenis gula pula jika diolah sendiri-sendiri. Apabila nira tersebut dididihkan kemudian dimasukkan dalam dekantasi berwarna relatif coklat, maka pertanda nira tersebut kurang baik. Sedangkan bila berwarna putih maka pertanda nira tersebut baik. Jika berwarna relatif coklat berarti nira tersebut telah mengalami inversi cukup besar, maka tindakan yang dilakukan adalah:

- Menambah setengah bagian lebih banyak Na-metabisulfit dan atau susu kapur.

- Pada saat pemasakan, suhu diusahakan rendah khususnya pada saat angkrop dan selama pemasakan dilakukan pengadukan.

Perolehan nira yang baik juga tidak terlepas dari perlakuan ketika penyadapan. Penyadapan yang baik biasanya menggunakan susu kapur yang dioleskan pada tabung penampung nira. Tujuannya pemberian susu kapur antara lain:

1. Menetralkan nira agar tidak terjadi inversi sukrosa (gula aren adalah kristal sukrosa). Jika terjadi inversi maka gula maka kristal yang dihasilkan berkurang, dan akan menghasilkan gula aren yang mudah leleh, kristalisasi gula aren akan terganggu. Penetralan nira juga dimaksudkan agar nira tidak mudah difermentasikan oleh aktivitas mikro organisme.

2. Sebagai bahan penjernih nira aren, karena kapur dapat bereaksi dengan asam-asam organik dan mineral dalam nira, membentuk gumpalan dan mengendap. Susu kapur dibuat dengan jalan menambah kapur tohor/ kapur matang $(\mathrm{CaO})$ dengan air. Bila ditulis dengan persamaan kimia:

\section{$\mathrm{CaO}$ (kapur tohor) $+\mathrm{H}_{2} \mathrm{O}$ (air) $\longrightarrow \mathrm{Ca}(\mathrm{OH})_{2}$ (susu kapur)}

Pada waktu penambahan susu kapur pada nira aren akan terjadi reaksi antara $\mathrm{Ca}(\mathrm{OH})_{2}$ dengan asam-asam organik dan mineral dalam nira, membentuk gumpalan-gumpalan dan mengendap. Reaksi ini akan terjadi lebih cepat bila nira yang telah ditambahkan susu kapur dipanaskan. Dengan memisahkan endapan maka hal ini akan memperkecil kadar abu dalam nira, yang berarti pula akan memperkecil kadar abu dalam produk gula aren. Untuk mendapatkan gula aren yang beragam dengan baik (warna coklat dan keras), nira gula yang 
beragam, baik derajat brix maupun pHnya harus mempunyai kadar gula pereduksi kurang dari 0.8 / ml. Nira seyogyanya dikumpulkan untuk diolah dalam kondisi yang sama sehingga produk akhir gula aren dapat seragam. Dalam standardisasi nira perlu diperiksa $\mathrm{pH}$ dan brix nira untuk selanjutnya ditambahkan susu kapur dan gula sukrosa agar nira yang beraneka ragam agar dapat sesuai dengan standar yakni mencapai 17\% brix dan pH 6-7 (Balai Pengkajian Teknologi Pertanian Bengkulu, 2003). Pengaturan pH nira yang akan diolah menjadi gula aren perlu dilakukan. Apabila $\mathrm{pH}$ nira terlalu tinggi akan terjadi reaksi pencoklatan (browning) yang dapat menurunkan rendemen gula aren yang dihasilkan. Demikian pula mutu simpan gula aren akan rendah, mudah meleleh karena gula aren mengandung air sehingga akan menurunkan kandungan sukrosa dan terjadi warna coklat gelap pada gula aren yang dihasilkan. Sedang bila $\mathrm{pH}$ terlalu rendah (kondisi asam) akan terjadi inversi sukrosa gula reduksi yang tinggi. Pada waktu pengolahan, $\mathrm{pH}$ nira aren yang baik berkisar 6,0-7,5 (Sapari, 1995).

Tabel 1. Perbandingan Gula Aren Sebelum dan Sesudah Kegiatan

\begin{tabular}{|c|c|c|c|c|}
\hline No. & Kriteria Uji & Sebelum & Sesudah & Standar (SNI) \\
\hline 1. & Keadaan & & & \\
\hline a. & Bentuk & Tempurung & Kotak & Normal \\
\hline b. & Rasa dan Aroma & $\begin{array}{c}\text { Normal, Kurang } \\
\text { Manis }\end{array}$ & Normal, manis & Norma, khas \\
\hline c. & Warna & Coklat Pucat & Coklat cerah & $\begin{array}{l}\text { Kuning coklat } \\
\text { sampai coklat }\end{array}$ \\
\hline 2. & $\begin{array}{l}\text { Bagian yang tidak larut } \\
\text { dalam air }(\%, \mathrm{~b} / \mathrm{b})\end{array}$ & 0.8 & 0.7 & Maks. 1.0 \\
\hline 3. & Air $(\%, b / b)$ & 10.1 & 8.6 & Maks. 10 \\
\hline 4. & $\mathrm{Abu}(\%, \mathrm{~b} / \mathrm{b})$ & 1.9 & 1.6 & Maks. 2.0 \\
\hline 5. & Gula Pereduksi $(\%, b / b)$ & 8.8 & 8.6 & Maks. 10 \\
\hline 6. & $\begin{array}{l}\text { Jumlah Gula Sbg. Sukrosa } \\
(\%, \mathrm{~b} / \mathrm{b})\end{array}$ & 85 & 74 & Minimum 77 \\
\hline 7. & Cemaran logam & & & \\
\hline a. & $\mathrm{Pb}(\mathrm{mg} / \mathrm{kg})$ & Negatif & Negatif & Maks. 2.0 \\
\hline b. & $\mathrm{Cu}(\mathrm{mg} / \mathrm{kg})$ & Negatif & Negatif & Mak. 10 \\
\hline c. & $\mathrm{Zn}(\mathrm{mg} / \mathrm{kg})$ & Negatif & Negatif & Maks. 40 \\
\hline e. & $\mathrm{Hg}(\mathrm{mg} / \mathrm{kg})$ & Negatif & Negatif & Maks. 40 \\
\hline 8. & Daya tahan & 24 hari & $>126$ hari & Tidak meleleh \\
\hline
\end{tabular}

Gula Aren merupakan produk yang dibuat dari penguapan nira tanaman aren (Arenga pinata). Nira aren diperoleh penyadapan bunga (mayang) yang diiris tangkai bungannya, sehingga keluar nira tetes demi tetes. Nira aren merupakan cairan yang terdapat didalam mayang atau manggar aren yang masih tertutup. Mayang atau manggar adalah bunga aren yang dijumpai pada pohon aren yang berumur 7-8 tahun, dimana mayang atau manggar ini berbentuk karangan bunga. Produksi optimal setiap mayang biasanya 15 hari. Hal ini tergantung dari berbagai faktor antara lain varietas aren, umur tanaman, iklim dan perawatan mayang. Jenis varietas sangat berpengaruh, pada varietas tertentu dapat berproduksi lebih dari 15 hari, namun ada pula yang kurang dari 15 hari. Umur pohon 7-8 tahun biasanya tanaman baru mulai belajar berproduksi dan pada umur 10 tahun akan lebih banyak menghasilkan nira dibandingkan pohon aren yang sudah tua dan masih muda (Tim Fakultas Pertanian Unib, 2002). Umur maksimal pohon bisa mencapai puluhan tahun. Iklim juga 
berpengaruh terhadap perolehan nira. Pada musim basah (musim hujan) produksi nira lebih banyak jika dibandingkan dengan ketika musim kering (musim kemarau). Kegiatan ini dilaksanakan pada saat musim kemarau, sehingga kandungan niranya rendah, namun kualitas niranya (kandungan brixnya) lebih tinggi.

Dilihat dari aspek kualitas, gula aren yang dihasilkan sesudah diadakannya kegiatan ini lebih bagus dibandingkan kualitas gula aren sebelum dilaksanakannya kegiatan ini, terutama kadar air, kadar abu, kadar kotoran, kandungan gula pereduksinya dan daya tahan simpan produk (Tabel 1).

Dilihat dari kandungan gizi secara umum perbedaannya tidak terlalu mencolok, antara sebelum dan sesudah kegiatan (Tabel 2). Kualitas nira sangat berpengaruh terhadap kualitas gula yang dihasilkan. Pada prinsipnya proses pengolahan gula kelapa hanya merupakan penguapan air bahan, sehingga brix yang ada akan mengental sehingga terbentuk gula (Sapari, 1995). Dari aspek bentuk dan ukuran terlihat bahwa gula aren sesudah kegiatan relatif lebih sama beratnya (bentuk kotak) dibandingkan produk gula sebelum kegiatan (tempurung) (Tabel 3).

Tabel 2. Perandingan Kandungan Gizi Gula Aren Sebelum dan Sesudah Kegiatan

\begin{tabular}{llrrr}
\hline No & Kandungan Gizi & Standar & $\begin{array}{r}\text { Sebelum } \\
\text { Kegiatan }\end{array}$ & Setelah Kegiatan \\
\hline 1. & Energi & $368 \mathrm{Kal}$ & $362 \mathrm{Kal}$ & $368 \mathrm{Kal}$ \\
2. & Protein & $0 \mathrm{~g}$ & $0 \mathrm{~g}$ & $0 \mathrm{~g}$ \\
3. & Lemak & $0 \mathrm{~g}$ & $0 \mathrm{~g}$ & $0 \mathrm{~g}$ \\
4. & Karbohidrat & $95 \mathrm{~g}$ & $94 \mathrm{~g}$ & $95 \mathrm{~g}$ \\
5. & Kalsium & $75 \mathrm{mg}$ & $75 \mathrm{mg}$ & 76 \\
6. & Fosfor & $35 \mathrm{mg}$ & $35 \mathrm{mg}$ & $36 \mathrm{mg}$ \\
7. & Zat besi & $3 \mathrm{mg}$ & $3.1 \mathrm{mg}$ & $3.2 \mathrm{mg}$ \\
8. & Vitamin C & $0 \mathrm{mg}$ & $0 \mathrm{mg}$ & $0 \mathrm{mg}$ \\
9. & Air & $10 \mathrm{~g}$ & 7.8 & 8.9 \\
10. & Bdd & $100 \%$ & $100 \%$ & $100 \%$ \\
\hline
\end{tabular}

Untuk Peningkatan nilai tambah, dibuat produk alternatif, yaitu pembuatan gula semut. Dari hasil kegiatan tersebut dapat diperoleh keuntungan yang empat kali lipat dari pada memproduksi gula aren. Setiap $1 \mathrm{~kg}$ gula aren dijual dengan harga rata-rata Rp. 3000, sementara gula semut dapat dijual dengan harga Rp 12.500 perkg. Meskipun proses pembuatannya agak rumit, namun harga jual yang cukup tinggi tersebut cukup menjanjikan untuk dikembangkan lebih lanjut. Dari lima kali produksi yang dilakukan produk gula semut tersebut dapat dijual ke pedagang pengumpul dengan harga Rp 12.500. Dari lima kali produksi dihasilkan rata-rata $40 \mathrm{~kg}$ dengan harga $\mathrm{Rp} 12.500$, sehingga rata-rata penjualan Rp 500.000 setiap kali produksi. Untuk lima kali produksi sudah dapat dihasilkan Rp 2.500.000. 
Tabel 3. Bentuk dan Ukuran Berat Gula Aren Sebelum dan Sesudah Kegiatan

\begin{tabular}{|c|c|c|c|c|}
\hline Jenis Perlakuan & Bentuk & $\begin{array}{c}\text { Berat } \\
\text { Rata-rata } \\
\text { (gram) }\end{array}$ & $\begin{array}{c}\text { Berat } \\
\text { Terendah } \\
(\text { gram }) \\
\end{array}$ & $\begin{array}{c}\text { Berat } \\
\text { Tertinggi } \\
\text { (gram) }\end{array}$ \\
\hline Sebelum Kegiatan & Tempurung & 594.12 & 553.36 & 725.15 \\
\hline Setelah Kegiatan & Kotak & 200.34 & 199.54 & 204.39 \\
\hline
\end{tabular}

Dengan demikian melalui kegiatan tambahan ini dapat memberikan keuntungan ekonomis yang cukup menjanjikan, karena diperoleh peningkatan harga lebih dari dua kali lipat. Keadaan tersebut baru menggambarkan satu pengrajin. Di desa ini terdapat $200 \mathrm{KK}$ yang $70 \%$ bermata pencaharian sebagai pengrajin gula aren dengan kapasitas produksi yang kurang lebih sama. Jika semua pengrajin dapat mengaplikasikan hasil kegiatan ini, maka diharapk kesejahteraan dapat meningkat. Dalam satu bulan desa ini dapat menghasilkan 750 ton gula aren yang biasanya dikonsumsi oleh rumah tangga, bahan baku pembuatan kecap, dan bahan baku produk olahan lainnya. Dengan demikian produk kegiatan ini mempunyai potensi ekonomis dan strategis, karena perbaikan teknologi dan pengembangan produk dapat meningkatkan harga jual dan jangkauan pemasaran (Nurcahyo, 2011; Nurmalina, dkk., 2009).

Melalui kegiatan ini dapat meningkatkan pengetahuan keterampilam kepada pengrajin tentang wawasan wirausaha, pengetahuan bahan baku, proses pengolahan, kualitas produk, pengemasan, teknik promosi dan pemasaran, dan manajemen pengelolaan usaha (Winarno dkk., 1990). Dengan teknologi yang diaplikasikan dapat diperoleh produk yang berkulaitas tinggi, tahan lama dan tidak mudah meleleh, ukuran, bentuk dan timbangan yang seragam, mempermudahkan dalam pengemasan, penyimpanan dan transportasi karena tidak memakan temat dan luasan ruang yang terlalu luas, dibandingkan bentuk gula aren selama ini yang tidak beraturan dan beragam ukuran, bentuk dan timbangannya. Dengan pengemasan dan pelabelan yang menarik diharapkan dapat meningkatkan daya terima konsumen, karena dewasa ini dengan majunya peradaban cenderung merubah persepsi konsumen tentang produk sejalan kesadaran konsumen tentang gizi, sanitasi, dan kesrhatan. Produk yang berkualitas dan menarik cenderung lebih diminati (Winarno, 1994).

Dengan harga gula aren yang tinggi diharapkan dapat mendorong petani atau investor untuk memperluas luas areal tanaman aren di propinsi Bengkulu yang selama ini masih belum dibudidyakan, masih tumbuh dan menyebar secara alami. Kawasan tanaman tanaman dapat berfungsi ganda yaitu sebagai kawasan konservasi dan sumber pendapatan masyarakat. Apalagi tanaman aren dapat dimanfaatkan secara optimal tanpa merusak lingkungan seperti ijuknya, akarnya, batang yang sudah mati, lidi, buah (kolang-kaling). Secara nasional dapat meningkatkan luasan tanaman aren.

Ditinjau dari aspek pengelolaan, manajemen yang dipakai dalam mengelola usaha masih sangat sederhana, yaitu menggunakan tenaga kerja yang merupakan anggota keluarga sendiri, yaitu Bapak, Ibu, keponakan dan anak. Upah tenaga kerja biasanya tidak dihitung. Meskipun sudah ada pembukuan, akan tetapi masih sangat sederhana. Pembagian kerja meliputu memanjat pohon aren untuk mengambil nira dilakukan oleh laki-laki (Bapak dan Keponakan) sedangkan pengolahan biasanya dilakukan oleh wanita. Biasanya nira diambil 
pada pagi hari dan sore hari. Sedangkan pemasakan dua kali yaitu pagi hari dan sore hari.

\section{Kesimpulan}

\section{KESIMPULAN DAN SARAN}

Dari hasil kegiatan yang telah dilakukan dapat diaplikasikan teknologi tepat guna untuk menghasilkan produk gula aren dan gula semut yang bersih, tahan lama, higienis dan bentuk menarik dan ukuran yang relatif seragam dibandingkan dengan teknologi sebelumnya. Dengan perbaikan teknologi yang diaplikasikan dapat menghemat penggunaan bahan bakar hingga $23 \%$. Disamping itu cara pembersihan dan sterilisasi yang lebih mudah karena alat penampung yang terbuat dari paralon bersifat lebih kedap dibandingkan bambu. Kualitas produk yang dihasilkan berdasarkan SNI lebih baik dibandingkan dengan kegiatan sebelumnya, namun dari aspek gizinya tidak menunjukkan perbedaan yang berarti. Dilihat dari berat per bijinya, gula aren setelah kegiatan berbentuk kotak relatif lebih seragam dibandingkan sebelum kegiatan. Dari aspek daya tahan simpan produk yang baru lebih lama meleleh (>126 hari) dibandingkan produk lama (24 hari). Dari harga jual tidak ada perbedaan antara produk lama dan produk baru, namun produk alternative yang dibuat berupa gula semut dapat meningkatkan harga jual hingga 4 kali lipat.

\section{Saran}

Untuk membantu para pengrajin perlu diupayakan keadilan mutu, dimana mutu yang 
baik harus dihargai dengan harga tinggi. Untuk itu perlu campur tangan pemerintah (Dinas Perindag Kabupaten Rejang Lebong) untuk menentukan harga yang adil bagi para pengajin, bukan tengkulak yang menentukan harga secara sepihak.

Perlu diupayakan pembinaan dengan skala yang lebih luas agar teknologi yang dipalikasikan dalam kegiatan ini dapat didopsi oleh pengrajin lain, tidak hanya pengarajin binaan. Untuk pemasaran gula semut diperlukan upaya promosi baik teknologi maupun pemarannya, sehingga diharapkan dapat membantu meningkatkan taraf hidup pengajin aren secara keseluruhan. Disamping perlu pula diversifikasi produk olahan gula semut, misalnya dalam bentuk kemasan sachet, jahe instant, kunyit instant, kencur instant dan lain-lain. Perlu pula dikaji pemanfaatan aren sebagai bahan pembuat alcohol untuk bahan baker alternative di kemudian hari.

Kebanyakan petani aren baru memanfaatkan nira aren, sementara buahnya (kolang kaling), lidinya, sagunya belum dimanfaatkan. Produk-produk tersebut jika dikelola dengan baik dapat menanampung lapangan kerja banyak dan meningkatkan taraf hidup masyarakat.

\section{UCAPAN TERIMA KASIH}

Penulis memberikan penghargaan kepada Bapak Sumarno dan Keluarga Besarnya yang telah bersedia bekerjasama dalam kegiatan ini, mulai dari persiapan, pelaksanaan,

monitoring dan evaluasi hingga selesainya penulisan laporan. Melalui kesempatan ini, penulis juga tak lupa mengucapkan terima kasih kepa Kepala Desa Air Meles yang telah memberikan izin dalam membantu pelaksanaan kegiatan. Terakhir Penulis menucapkan terima kasih kepada Direktorat Penelitian dan Pengabdian Masyarakat yang telah mendanai kegiatan, sehingga kegiatan ini dapat berjalan dengan lancar.

\section{DAFTAR PUSTAKA}

Balai Pengkajian Teknologi Pertanian Provinsi Bengkulu, 2003, Kumpulan Imformasi Teknis Teknologi Pasca Panen Beberapa Produk Pertanian, Perikanan, Perkebunan dan Peternakan.

Biro Pusat Statistik, 2004, Bengkulu Dalam Angka, Kantor Perwakilan Statistik Propinsi Bengkulu.

Tim Fakultas Pertanian UNIB, 2002, Rancang bangun kawasan agribisnis di pedesaan Propinsi Bengkulu, Kerjasama Fakultas pertanian UNIB dan Departemen Pertanian Indonesia, Bengkulu.

Kanwil Perindustrian dan Perdagangan Propinsi Bengkulu, 2004, Data Base Komoditi Unggulan Industri Hasil Pertanian dan Kehutanan Propinsi Bengkulu 1998/1999.

Lay A., Bambang H., 2011, Prospek Agroindustri Aren (Arenga pinata), Jurnal Teknologi Industri Pangan. Perspektif 10 (1) : 1-10. 
58 Dharma Raflesia Unib Tahun XIV, Nomor 1 Juni 2016

dihasilkan di Beberapa Sentra Produksi di Bengkulu. Jurnal Penelitian UNIB Vol. XI (1): $42-48$.

Marsigit, W., 2010, Pengembangan Diversifikasi Produk Pangan Olahan Untuk Menunjang Ketahanan Pangan Berkelanjutan, Jurnal Teknologi Pertanian Agritech 30(4) : 265273.

Nurcahyo, D.F., 2011, Analisis Kelayakan Bisnis. Fakultas Teknik Universitas Indonesia, Depok.

Nurmalina R., Sariant T., Karyadi A. 2009. Studi Kelayakan Bisnis Pertanian. Departemen Agribisnis, Fakultas Ekonomi dan Manajemen, Institut Pertanian Bogor.

Safari, Ahmad, 1995, Teknik Membuat Gula Aren, Karya Anda, Surabaya.

Sukarto., S.T., 1990, Pengenalan Konsep Pengendalian Mutu, Fateta IPB, Bogor.

Susanto, T dan B. Saneto, 1994, Teknologi Pengolahan Hasil Pertanian, Bina Ilmu, Surabaya.

Winarno, F.G., S. Fardiaz dan D. Fardiaz, 1990, Pengantar Teknologi Pangan, Gramedia Jakarta.

Winarno, F.G., Sterilisasi Komersial Produk Pangan, Gramedia Pustaka Utama, Jakarta.

Winarno, F.G., dan T.S. Rahayu, 1994, Bahan Tambahan Untuk Makanan dan Kontaminan, Pusbangtepa-IPB, Pustaka Sinar Harapan, Jakarta. 